\title{
Environment and Society
}

An Introductory Analysis 


\title{
ENVIRONMENT AND SOCIETY An Introductory Analysis
}

\author{
Brian Harvey \\ Department of Adult Education, \\ University of Nottingham \\ and \\ John D. Hallett \\ Department of Education, \\ Trent Polytechnic
}


(C) Brian Harvey and John D. Hallett 1977

Softcover reprint of the hardcover 1st edition 1977

All rights reserved. No part of this publication may be reproduced or transmitted, in any form or by any means, without permission.

First published 1977 by

THE MACMILLAN PRESS LTD

London and Basingstoke

Associated companies in New York Dublin

Melbourne Johannesburg and Madras

ISBN 978-0-333-18416-5 ISBN 978-1-349-15799-0 (eBook)

DOI 10.1007/978-1-349-15799-0

This book is sold subject to the standard conditions of the Net Book Agreement.

The paperback edition of this book is sold subject to the condition that it shall not, by way of trade or otherwise, be lent, re-sold, hired out, or otherwise circulated without the publisher's prior consent in any form of binding or cover other than that in which it is published and without a similar condition including this condition being imposed on the subsequent purchaser. 


\section{Contents}

1 Basic Ecological Principles 1

1.1 The Movement of Materials in the Biosphere 2

1.2 The Flow of Energy in the Biosphere 10

1.3 The Interrelationship between Materials and Energy 13

2 Population and Food $\quad 17$

2.1 The Growth of World Population 17

$\begin{array}{ll}2.2 & \text { Population Dynamics } \\ 2.3 & 23\end{array}$

2.3 The Basic Needs for Survival 25

$\begin{array}{lll}2.4 & \text { The Techniques of Agriculture } & 28\end{array}$

3 Energy, Materials and Pollution $\quad 37$

3.1 Harnessing Energy $\quad 39$

3.2 Material Resources $\quad 45$

3.3 Disposal and Pollution $\quad 49$

4 The Environmental Debate $\quad 62$

4.1 The Development of the Debate 63

4.2 Positions in the Debate 76

4.3 Approaches to the Solution of Environmental Problems 82

5 The Politics and Economics of the Environment 86

$\begin{array}{lll}\text { 5.1 Choice in the Use of Resources } & 87\end{array}$ 
vi Contents

$\begin{array}{lll}\text { 5.2 Decision-making Systems } & 91\end{array}$

5.3 Unintended Consequences and Conflicts of Interest 94

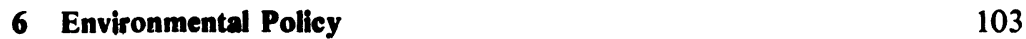

6.1 Policies towards Pollution 103

6.2 Resources, Population, Technology and the Social Environment 119

7 An Evolving Post-industrial Society? 130

7.1 The Causes of Social Development 132

$\begin{array}{ll}7.2 & \text { Thinking about the Future } \\ 7.38\end{array}$

7.3 Technology, Growth and Change 140

$\begin{array}{lr}\text { References } & 151\end{array}$

$\begin{array}{lc}\text { Further Reading } & 158\end{array}$

$\begin{array}{ll}\text { Index } & 160\end{array}$ 


\section{Preface}

The environmental debate - a combination, difficult to define, of such overlapping issues as population growth, pollution, resource depletion, the distribution of resources between developed and less-developed nations, the relationship between economic growth and social welfare, the pace and direction of technological change- began to take shape during the late 1960s. Of course the separate issues were there before, and some individual writers had begun to make connections, but more widespread awareness stems from this period.

Books of the period have dramatic titles such as Planet in Peril, Only One Earth, The Closing Circle, A Blueprint for Survival, and The Limits to Growth. Yet it was in the late 1960s that the developed nations of Japan, Western Europe and the United States of America were experiencing unprecedented levels of material prosperity. There was confidence that, in the First Development Decade (as the 1960s were designated), the transfer of capital and expertise would also set the less-developed countries on the path of self-sustaining growth. Later, a recession in world trade and in economic growth, and more particularly the oil crisis (although, arguably, specific phenomena not centrally relevant to the general environment issue), did yield some insights into the practical implications of the Club of Rome's resourcedepletion calculations. Initially, however, widespread scepticism was understandable, given the economic background, the dramatic (sometimes melodramatic) presentation of environmental issues, the speculative nature of the topic and the range of emphases and opinions.

Whatever the swings of magnitude and focus of public and official interest, the authors of this book accept that the environment issue is here to stay and will become increasingly integrated into the stream of public policy. This is reflected partly in the growth of undergraduate courses in this area, which the book aims to serve. It therefore sets out to summarise the environment debate 
and survey the issues that compose it, from both a natural and social scientific viewpoint. Primarily intended for students on multidisciplinary courses, it:

(1) plots the development of the environment issue;

(2) outlines the different positions that have been taken on the nature, causes and treatment of environmental problems;

(3) presents the readily available overview of the different elements of the topic, in particular: (a) the basic natural science relevant to ecology, resources, pollution and population growth; and (b) the politics and economics of environmental problems and policies.

The book is written with the non-specialist reader in mind. Coming to a broadly based course on the environment, someone with a natural science background will find here a brief summary of relevant scientific topics. He will also find an introduction to the problem in its social-political-economic context, asking why environmental problems occur and what responses might be made to them. The same applies to a student with a social science background. The essential material for the non-scientist on ecology, pollution, etc., is provided in the early chapters. Contact with environmental issues on earlier courses will probably have been as brief illustrations of particular topics like external costs in economics, or pressure groups in political theory. So in the later chapters there will be found a systematic application of the social scientific approach to environmental issues. Suggestions for further reading on specific topics in each chapter, and detailed references, are grouped at the end of the book.

Chapter 1, 'Basic principles of Ecology', establishes the basic idea of global ecology by examining natural processes that occur in the absence of man: the conservation laws for materials and energy; cycles of materials and flow of energy as they affect life; the efficiency of energy transformations; photosynthesis, food chains and food webs. The factual information available on population globally and in particular countries is presented in chapter 2 , together with the arithmetic of population growth. The ideas of exponential growth and doubling period lead to a discussion of trends and forecasts, the factors that control the growth of animal populations and man's ability to avoid these natural controls. The chapter then considers the basic survival needs, the production of food and the techniques of agriculture. Chapter 3 is concerned with resources (the technical and economic aspects of meeting demands for fuels and materials; the energy budget and equilibrium sources of energy; the lifetimes of scarce resources) and pollution (the disposal of 
energy and materials as waste; dilution and mixing in water and atmosphere; the disturbance of natural cycles).

Chapter 4 surveys the development of the environment debate and summarises the positions taken on its causes and treatment by some of the main contributors. The focus of chapter 5 is on the framework of society within which environmental problems occur. The decision-making processes of society are reviewed and the point made that environmental problems are better regarded as an integral part of ongoing political-economic processes rather than as a separate issue. On the basis of this analysis, chapter 6 considers various approaches to environmental policy: taxes, subsidies and the role of government and law in the fields of pollution, resource depletion, population growth, the development of technology and the social-industrial environment.

The final chapter asks the question: will environmental problems respond to these reforms, or do they demand more fundamental changes in the structure of society? By referring to writers such as Illich, Ellul, Roszak and others, it examines the questions that command attention today. What are the forces that are thought to shape societies? What possible futures are projected or foreseen for ours? Is a post-industrial society evolving? If it is, what form would it take, and would continued economic growth be a part of it? What will be the position of technology: a tyranny of high technology or a humanised intermediate technology? What path will we take to any future society-can we build on ideas and institutions already in existence, however radical, or will there need to be a catastrophe? 